\title{
ECOM Coffee Group: The Hybrid Plant Decision
}

\author{
Roy Zúñiga and Bernard Kilian \\ INCAE Business School, Costa Rica
}

\section{roy.zuniga@incae.edu bernard.kilian@incae.edu}

Keywords: case study, coffee exporter, resistance to change

\begin{abstract}
A team of students, with faculty supervision, analyze the agribusiness chain of a major global coffee exporter and make recommendations regarding the strategy for introducing hybrid plants for the renovation of coffee growers' plantations. Based on the student analysis, a case study is developed and subsequently discussed among the faculty, the student research team, and the case protagonists, opening new informing pathways and overcoming grower resistance to the change
\end{abstract}

Material published as part of this publication, either on-line or in print, is copyrighted by the Informing Science Institute. Permission to make digital or paper copy of part or all of these works for personal or classroom use is granted without fee provided that the copies are not made or distributed for profit or commercial advantage AND that copies 1) bear this notice in full and 2) give the full citation on the first page. It is permissible to abstract these works so long as credit is given. To copy in all other cases or to republish or to post on a server or to redistribute to lists requires specific permission and payment of a fee. Contact Publisher@InformingScience.org to request redistribution permission. 